\title{
The Effect Of Work-Life and Social Media Balances On Moslem Family Teachers In Pandemic Time
}

\author{
Anizar Rahayu ${ }^{1}$, Abdul Rahman Shaleh ${ }^{2}$, Rosleny Marliani ${ }^{3}$ \\ ${ }^{1}$ Universitas Persada Indonesia YAI \\ ${ }^{2}$ Universitas Islam Negeri Syarif Hidayatullah Jakarta \\ ${ }^{3}$ Univeristas Islam Negeri Sunan Gunung Djati Bandung \\ Corresponding Email : roslenymarliani@uinsgd.ac.id
}

\begin{abstract}
Distance learning demands extra work and adjustment of teachers in doing a task to educate their students. This condition causes a conflict such as interfering with wholeness that leads to family resilience conflict. In Islamic teaching, family resilience can be achieved by living the principles of zawaj (pair), mitsaqan-ghaliza (solid bond), musyaran (good association), and musyawarah (mutual agreement) in relationship between family members. The study aimed to find out the effect of worklife and social media balances on teachers' families' resilience and was measured by Islamic family resilience values. The participants were 161 teachers aged 21-36 years in Cikarang area of Bekasi Regency who used social media. Data was taken through Google-form with three scales, namely Islamic Family Resilience which was developed by Islamic family resilience aspect of BP4 called IMRS $®$, the scale of work balance was from Fisher, Bulger, \& Smith (2009), and the scale of social media balance was from Kumar \& Priyadarshini (2018). Data was taken by a nonprobability sampling with purposive sampling technique. The data were analyzed with multiple regression analysis. The results showed that the variables of work-life and social media balances had a significant effect on family resilience. The study also showed that three dimensions had a significant effect, namely (2) the mixing of person to work, (3) enrichment of personal life from work, and (6) the use of social media for personal. This study implied that the importance of understanding family members related to the fulfillment of common goals and must be communicated.
\end{abstract}

Keywords: Work-Life Balance, Use Of Media Social, Islamic Family Resilience

\begin{tabular}{|c|c|c|c|c|}
\hline Submission & Review Process & Revised & Accepted & Published \\
\hline April 15, 2021 & $\begin{array}{c}\text { October 26, 2021 - } \\
\text { December 5, 2021 }\end{array}$ & December 13, 2021 & December 14, 2021 & December 29, 2021 \\
\hline
\end{tabular}

\section{Introduction}

The involvement of teachers actively in the education world as educators cannot be replaced by anything. The contribution of teachers is from various sides, ranging from the substance material to attention and dedication showed and makes teachers a major factor in success in the education world (Darmadi, 2015). It is not an easy thing to do. Formally, the duty and responsibility of teachers in Indonesia have indeed been regulated in UU RI No.14 in 2005 concerning Teachers and Lecturers. In Chapter IV Article 14 paragraph 1 , it is mentioned that doing their duties as a teacher, teachers deserve to have the opportunity to play a role in determining education policy, developing and improving academic qualification and competency. The duty and responsibility shared by teachers are also accompanied by technological advances and globalization and provide additional challenges for teachers in their role in the education world in Indonesia (UURI Number 14, 2015).

An additional problem for teachers today is the Covid-19 pandemic situation. News quoted from The Editor (2020) revealed that distance learning forced the teachers to serve the learning process with learners online, beyond tasks and other responsibilities. This 
situation becomes such pressure in itself. Working from home, the demands of technology, as well faced with other tasks, become challenges and difficulties for teachers in work life. This situation can bring influence into the smallest environment, namely the family (Akbar \& Tahoma, 2018; Agustina \& Broto, 2019).

Families are faced with challenges and they must be faced together. Decreased interaction between family members and other family members, threatened health, and other behaviors (Hawley \& Dehaan, 1996) require adapting and surviving through the most difficult situation that is happening. From a psychological perspective, this ability is known as resilience.

Resilience is generally defined as the ability and success of adapting to difficult situations and rising beyond those situations (Reivich \&Shatte, 2002). The concept of resilience becomes an interesting topic of discussion to be studied further in various challenges faced in difficult situations, one of which is in the family. Family resilience develops after there are research and theory developed by several experts in the context of stress, coping, and family adaptation (Mawarpury \& Mirza, 2017).

Individual resilience and family resilience have differences in the concept of family resilience which are focused on a positive perspective, have the family as one of the units to have own strength and communicate with each other. While individual resilience has a focus on the development of each individual's life and how individuals can be resilient in the face of difficulties and challenges of life (Mawarpury \& Mirza, 2017). Mackay (2003) defined family resilience as a condition in which a family can become more or less resilient based on one particular situation. Another definition of family resilience is described by Walsh (2002) as family resilience is a process of coping and adaptation within a family that serves as a functional unit to difficult or stressful situations. Walsh further explained the adaptive coping used by resilient families such as adaptation, adjustment, and family development in a more positive direction. It can be concluded that family resilience is interpreted as the success of the family in adapting and succeeding in overcoming the difficulties faced by the family.

The category of families is not resilient and it can provide difficult situations not only for husband and wife but also for their family conditions. Nevid, Rathus, \& Greene (2005) suggested that inappropriate behavior, unable to perform functions or roles can arise if a family does not have resilience. Furthermore, Fergilia et al (2012) in their research said a category of the family is not resilient and it can have a negative influence on the mental development of their children.

The category of the family is resilient and it can provide protective factors for family members. Protective factor possessed by a resilient family is to prevent negative outcomes in the family when facing difficult situations. One form of protective factor is that each family member can provide benefits to each other such as increased self-esteem, psychological well-being. Children who are in a resilient family also have the view that their family is more positive and they have the power related to concern, respect, and support and have good communication (Knaub, P, 1986).

In the Islamic concept, adjustment between family members becomes important in the starting of the sakinah family. The sakinah family is characterized by feelings of calmness and a tendency to pour out a sense of love and affection (QS. Ar-Ruum: 21). This adjustment process becomes important thing because sakinah is built on mawaddah and rahmah which requires the meaning and benefits of affection that people feel to give 
and receive love. Therefore, peace is not a onesided feeling but a peace rooted in both having and nurturing love, making ourselves happy as well as happy for others. Each partner needs to understand each other's positions and roles.

The family in Islam must be built from four principles, namely: zawaj (pair), mitsaqan ghaliza (solid bond), musyaran bil ma'ruf (good association), and musyawarah (mutual agreement). These four principles become the main pillars of marital buildings even in difficult situations, as well as pillars for the resilience of Islamic families (http://bimbinganperkawinan.com/empatpilar-perkawinan-dalam-islam/).

Zawaj as the first principle is described as a situation in which husband and wife believe that they are bound in marriage as a couple (zawaj) who complement each other. Like a bolt, they have to fill each other with their roles, duties, and responsibilities. To complement each other, they help each other and fill each other. The Qur'an likens this zawaj as clothing. "They are clothes for you, and you are clothes for them" (2:187). Like clothes, they protect each other, guard, and even close the family disgrace so that the family becomes strong and nurtured. This belief arises in married couples who believe that they can face every problem and overcome it together. Husband and wife help each other toward serenity (sakinah) (for example AsySyawi, 2004)

The second principle, mitsaqan ghaliza is described as a strong bond of marriage between husband and wife that is spoken at the marriage ceremony. Surah an-Nisa:21 means "How will you take it back when some of you have mingled with others as husband and wife. And they (your wives) have taken from you a great covenant ( strong)" and it mentions marriage is a great promise. The principle of mitsaqan ghaliza arises in the form of behavior that maintains the integrity of the great promise in marriage through personal commitment to maintain the integrity of the family. In marriage and family, therefore, husband and wife have the commitment and have the power of the holy promise as a firm, they are strong even they have a serious problem someday. Husband and wife both hold firm to marriage as a firm promise. Husband and wife both live marriage as a solid bond (Asy-Syawi, 2004).

The third principle in starting Islamic family resilience is mu'asyaran bil ma;ruf. This principle is described as a situation of a husband and wife who respect each other and treat their partner with dignity through the command "And associate with them properly"(an-Nisa:19). The husband or wife accepts and respects their differences and makes morality a basic value in treating a spouse. The typical behavior for a married couple is the determination to build confidence in facing family life, prioritize communication, and treat the couple well (Asy-Syawi, 2004).

Deliberation as the fourth principle is described as a relationship of agreement based on deliberation for a good thing in the family. In QS. Al-Baqarah: 233 "If they both decide on weaning (before two years) by mutual consent and consultation" and it is clear decisionmaking based on willingness and deliberation. Any issues in the family are resolved together through agreed decision-making (AsyShamawi, 2004). To find this agreement requires honesty and openness in communication. The typical behavior is an open attitude and clear communication between husband and wife.

Based on the explanation, a review of the literature about the studies of resilience showed that family resilience can be influenced by external factors as well as situational factors (Patterson, 2002; Fergilia et al., 2012). Internal factors are factors derived from the individual self, including the regulation of emotions, meaning of life, religiosity, spirituality, and self-confidence (Dumaris \& Rahayu, 2019; Fergilia et al., 
2012; Poegoeh \& Hamidah, 2016). Situational factors are factors that come from outside the individual self, including work-life balance, communication, social media balance, financial management, time, and recreation (Patterson, 2002). This research focused on work-life and social media balances.

The concept of work-life balance is shown variously by some researchers (Jones, Burke, \& Westman, 2013). Balance in the Islamic perspective is explained through the principle of justice of treatment in the muasyarah bil ma'ruf. This treatment requires each partner to respect each other and has an equal role function. One of them is to appreciate each other's abilities and competencies. Al-Khasyid (1999) mentioned that this principle is illustrated in an attitude of tolerance, good exchange, and a sense of togetherness based on justice, compassion, and mutual respect. Appreciating each other's abilities is shown by filling each other's limitations with personal self-advantage followed by the behavior of keeping the couple's secret. One of the treatments is to share roles when one of them cannot fill the role due to work conditions or other things. This treatment will minimize conflict between the couple and family members.

The work-life balance first refers to the absence of conflict in carrying out work and family functions (Grzywacz \& Carlson, 2007). However, it seems that this concept is not very adequate in showing an understanding of work-life balance, related to the concept of fulfilling the concept of family work (Voydanoff, 2004) or the concept of family work enrichment (Greenhaus \& Powell, 2006). In addition, situations are affected and caused by the work-life mixture and will affect the use of the term interfere (mixing), fulfillment, or enrichment (Grzywacz \& Carlson, 2007). It can be concluded that the work-life balance is understood as the existence of the individual when there is satisfaction in carrying out work and family roles (Greenhause, Collins, \&shaw, 2003) with a lack of conflict (Clark, 2000). Individuals can organize responsibilities with priorities of choice (Marks \&MacDermind, 1996) and can negotiate roles in work and family life. (Grzywacz \& Carlson, 2007). Based on some explanations, work-life balance is understood as situations and conditions that are assessed positively and negatively from the mixing and enrichment of roles in work and life roles. This mixture is described in four dimensions, namely work interference with personal life, personal life interference with work, personal life enhancement of work, and work enhancement of personal life (Fisher, Bulger, \& Smith, 2009).

In a cultural context, women have a difficult experience in work and family adjustments. In Indonesian culture, working women are still required to fill their domestic roles. In these conditions, working women will find some difficulties to achieve family-work balance. Keene \& Quadagno (2004) showed that $60 \%$ of working adults had difficulty achieving balance, especially if they have children less than 18 years. Moreover, balancing both of them becomes important for women if they do not want the pressure to hurt work or even on their family life (marriage). The work-life and personal life are interconnected and independent. A lot of works, meeting clients, job demands will interfere and affect the positive or negative personal life in the family, as a wife, and as a mother. On the other hand, work is necessary to fulfill household income. It can be concluded that working life can also affect positively or negatively for working life. Personal life, especially if there is a child, can lead to reducing time to finish the work, work stress, and loss of concentration at work. In this context, Hakim (2002) divided working women are based on their orientation into home orientation, adaptive, and work orientation. Inability to manage work-life and 
mixing by choosing to be oriented to one of them alone and sacrificing other activities can have an impact on dissatisfaction with a personal, partner, and other family members. This situation can lead to conflict and can lead to disruption of family resilience.

For a teacher, duty and responsibility as teachers especially in the pandemic era of teaching and learning activities are done at home, and life as a wife and parent must accompany children and husbands. This case will also be interpreted as a negative thing. The teacher will often complain and vent to their husband and children. Thus, resilience in the family cannot be achieved.

Another factor is the balance of social media. The development of technology influences various sectors of life, including in the education sector. Stafford and Griffis (2008) described social media as inseparable from the lives of each individual in this era and it can have a negative impact in the form of excessive use of social media. It is characterized by the presence of unstable emotions, interpersonal problems, and psychological problems. Social media balance is defined as the situation experienced by individuals over the balance of social media use in personal life with work life and is reflected in the behavior of individuals in their environment (Kumar \& Priyadarshini, 2018).

The use of social media both in personal affairs and work becomes a common thing in society, especially if it is associated with the teaching system done by a teacher in the Covid-19 pandemic and becomes uncontrolled. This is evidenced by a teacher often spending time in front of a laptop screen to teach via video conference, checking email as one of the alternative ways in sending tasks during PJJ, after completing teaching time is still often found teachers use their time to check on social media such as Twitter, Instagram, Tiktok. If the activities continue the balance of social media owned by teachers, it will not be achieved. The time to rest or gather with family becomes reduced, and direct interaction between families is reduced. Thus, the resilience of the family will not be achieved.

If the teacher can divide the time of use in social media both in work affairs and personal matters, the interactions owned between family members will be maintained directly. The parent and children will feel given affirmations and affection. If the balance in social media is successfully achieved, it can be said that the balance of social media influences family resilience.

In addition, it is not surprising that Islam guides how to position an equal role through the bonding of the pillar mitsaqan ghaliza and musyarah bil ma'ruf. Mitsaqan ghaliza wants the husband or wife to carry out the role well to maintain the commitment spoken as part of the promise (aqad nikah). In implied promise, the ability to share time is between ourselves, wife or husband, and family. This ability is accompanied by the right to be served and kept secret. This guidance becomes a guideline in playing social media for work and personal for beneficial things, not for something useless. Work and personal issues are not allowed to be expressed in a clear form, but rather expressed as a narrative of advice without showing personal and partner weaknesses. The duties and responsibilities in the family are not unilateral authorities but become both responsibilities. Therefore, any problems experienced by each partner become an important thing and must be supported by each other and resolved with the pillar of deliberation.

Based on phenomena and various sources about family resilience, the authors were interested in researching the point of view of a Moslem teacher, especially in pandemic situations. Teachers carry out professional roles at home and become a place for family values. Would Moslem family values be 
compromised by working from home? Did social media create benefits for families or become a source of prolonged conflict and disrupt family resilience? On that basis, the study was formulated into whether there was a significant effect of work-life and social media balances on family resilience?

\section{Research Methods}

The population in this study was 161 teachers who worked in Cikarang, Bekasi Regency. Young generations were individuals born between 1980 and 2000. They mostly work under various pressures, but they expect work-life balance (Smith J \& Nichols, 2015). The entire participants were Moslem who taught in public and private schools.

The data was taken through a nonprobability sampling approach and purposive sampling technique. The criteria of participants in the study were: teacher, married, and ages 21-39 years.

The research instrument was a questionnaire that was distributed on May 19, 2020, and closed on May 30, 2020. Questionnaires were filled out by participants and were accessed through Google Form and questionnaires at private Islamic schools in Cikarang. Data were distributed to as many as 161 people. Family resilience is developed by researchers using the four pillars of BP4 as a dimension for Islamic family resilience. The four pillars are used as the principle of the Islamic family, namely zawaj, mitsaqan ghaliza, bil ma'ruf, and deliberation. Based on four principles, a measuring scale is developed and compiled, called the Islamic Based Marital Resilience Scale (IMRS®). Work-life balance was developed using dimensions from Fisher, Bulger, \&Smith (2009) that measured four dimensions including the dimensions of work interfering with personal life (wipl), personal life interfering with work (pliw), personal life improving work (plew), and work improving personal life (wepl). The balance of social media was adapted from the Kumar \& Priyadarshini Scale measuring tool (2018) which explored the dimensions of social media use in work life (msp) and in personal life (msk).

Each scale had a reliability score of 0.751 for the Islamic family resilience scale, 0.819 for the work-life balance scale, and 0.892 for the social media balance scale. The data were analyzed with multiple regression analysis techniques.

\section{Results and Discussion}

The participants in the study were 161 female teachers in Cikarang, Bekasi Regency, West Java, with ages between 20-36 years with 21-25 years (13\%), 26-30 years (20.0\%), 3135 years $(20 \%)$ and 36 years $(47 \%)$. Multiple regression analysis results showed the value of $\mathrm{R} 2=0.456$ with a significance of 0.000 . based on multiple results, the proportion of variants of family resilience described by the use of social media balance variable and work-life balance was $45.6 \%$ while $55.4 \%$ was affected by other variables outside of the study. It can be interpreted that all independent variables and in total had a significant effect on the family's defense. The next step was to test whether all dimensions of independent variables had a significant effect on family resilience.

Table 1.

\begin{tabular}{ccc}
\multicolumn{3}{c}{ Regression Analysis Result } \\
\hline $\begin{array}{c}\text { Model/Variables/ } \\
\text { Dimensions }\end{array}$ & $\begin{array}{c}\mathrm{R}^{2} / \text { Beta/R }^{2} \\
\text { change }\end{array}$ & Sig. \\
\hline ALL MODEL & 0.456 & $\begin{array}{c}0.000 \\
*\end{array}$ \\
MSP & .007 & .277 \\
MSK & .120 & $.000^{*}$ \\
WIPL & .000 & .836 \\
PLIW & .077 & $.000^{*}$ \\
PLEW & .248 & $.000^{*}$ \\
WEPL & .003 & .361 \\
\hline
\end{tabular}


Based on table 1, it can be concluded that there were three dimensions and the regression coefficient was significant, namely: (2) the mixing of person to work, (3) enrichment of personal life from work, and 6) the use of social media for personal influences significantly, while the other three dimensions were (1) the mixing of work, (4) enrichment of work into life, and (5) the use of social media for the profession was not significant. The largest contribution from variables was (2) of personal-to-work mixing (0.248) and 6) personal social media use $(0.120)$. It can be concluded that the mixing of personal life and the use of social media for personal matters was the biggest contributor in influencing the resilience of Islamic families. From these results, there were only three dimensions that affected family resilience, namely (2) personal mixing to work, (3) enrichment of personal life from work, and 6) the use of social media for personal. Of these three dimensions that had the most effect were two dimensions of the balance of social media, namely (2) the mixing of person to work and 6) the use of social media for personal. While the other three dimensions were, namely (1) the mixing of work into life, (4) enrichment of work into life, and (5) the use of social media for the profession had no effect in the model studied.

Family resilience is a positive condition that describes all families to commit to maintaining family harmony and achieving a common goal in the family. The tendency to establish harmonious and mutually supportive communication is key to this concept (Mawarpury \& Mirza, 2017), although this condition cannot change to be non-resilient or be in a negative situation in a certain situation (Mackay, 2003). These negative situations resilience are shown (Walsh, 2002) and requires adaptive coping such as adaptation, adjustment, and family development in a more positive direction, if the people do not want to put the family and marriage in difficult situations and tend to be negative because the behavior is not appropriate for one of the members in carrying out function and role in the family (Nevid et al. 2005; Fergiliia et al, 2012).

Teacher as a noble profession is not faced with difficult choices when the teacher must complete to educate the students or to prioritize the family. On the other hand, the teacher does tasks not only to give lessons but to guide. The teacher is also required to pay attention and care for learners. Especially in a pandemic situation, the process of learning provides its challenges. The teacher is required to have an extraordinary ability for distance learning with many additional roles. Ensuring learning objectives, academic or non-academic targets, preparing a relevant lesson and technical evaluation can measure face-to-face learning and only part of the process must be faced, especially in maintaining closeness. Touch, the safety of learners, communication with colleagues and superiors are some of the real challenges for a teacher.

The importance of the role of teachers in the pandemic does not necessarily call as the "vanguard against Covid-19", but the teacher's job is timeless. Moving the learning process to home is difficult and needs a lot of time to think. The integrity of work and personal function becomes inevitable. In addition, the ability of other teachers is required to keep the family and marriage harmonious and intact.

The focus of this study was to find out the effect of work-life and the use of social media balances on family resilience. The results showed that work-life and the use of social media balances significantly affected family resilience with regression scores $\mathrm{R} 2=0.456$. It means $45.6 \%$ of family resilience could be affected by dimensions in the worklife balance variable and social media balance. In addition, it can be suspected that both the variables and the dimensions affected family resilience. 
However, it can be seen the percentage score of variants from regression analysis conducted was not all dimensions which showed a significant contribution. There were only three dimensions of a significant worklife balance: (2) personal-to-work mixing, (3) enrichment of personal life from work and 6) personal use of social media. While, the two dimensions of WLB were (1) the mixing of work into life and (4) enrichment of work into life, as well as one dimension of the use of social media ((5) the use of social media for the profession), were not significant.

The finding showed that balancing the work of life was an important thing about maintaining a family, especially about paid work, referred to as family responsibility (Dex and Scheibl, 2001; Rotondo et al., 2003). A family with few members will be in good condition or there is no problem (Waumsley, Houston and Marks, 2010) because it exerts lower pressure and can be more manageable. In other words, family functions and the adjustment process are easier to do (Sunarti, 2001).

The result of the study showed the negative score on regression score was found on two dimensions of the mixing of work into life and the mixing of life into work as well as positive on the enrichment of work into life and there was no significantly on the enrichment of life to work. It means that the importance of the family where the mixing of work and enrichment of work will be a very important thing compared to personal enrichment to work in family life.

This is in line with Islamic guidelines in building a family. The family in Islam is built on a tendency to reassure and soothe with a feeling of love (Machrus, 2017). Sincere love is based on the principle of mawaddah and rahmah. This principle explains mutual benefit and feels the benefit of affection with mutual care and fulfilling treatment. Maintaining and fulfilling treatment of each partner well is to treat the partner adaptively. It means seeing the development of the situation to fill each other and appreciate each other to maintain a family (QS. At-Tahrim: 6). This situation of caring for each other creates hell symbolically and it means unresolved disputes. Therefore, it is not surprising that the mix of work-life is significant in creating a calm and peaceful atmosphere in the family. Balance becomes important when a couple cannot maintain this balance in the family. The result showed a positive direction in work-life balance and it means the situation in the subject's household went accordingly.

This is in line with family values and meaning. The ideal meaning of family existence for most of us is lasting happiness, love, friendship, confidence, excellent health, financial security, and also the fulfillment of self-development, based on sacred bonds and should not be underestimated. Therefore, any business outside the family, including marriage should not interfere because it will also interfere with resilience, but is expected to enrich or strengthen the family.

One way to strengthen family resilience is a financial factor and role functioning. Income becomes an important thing associated with every income achieved and will be used as a facilitation of family need. In line with that Sunarti and Herawati et al (2012) explained that the increase in income generated from work would increase family resilience because it could help family what the family needs. From the result of the study, it can be concluded that the income of the teacher's family was relatively adequate because more than $70 \%$ of the teacher had a housekeeper.

This condition strengthens the explanation of research findings related to the functioning of the role. Some roles have been done by a housekeeper who is paid for them. Referring to Basharpoor and Sheykholeslami (2015), this is a kuncul for family resilience. As long as the functions of the role in the 
family are still running, the resilience of the family will be fulfilled. The fulfillment of this function is one of them supported by the continued work of women as an important part of the family's needs. From this study it can also be understood the more clearly the impact of work on the family, the higher the resilience.

The dimension of the balance of social media did not have a significant effect on family resilience. It showed that the use of social media seems to become an important part of life. Teachers and other family members are familiar with the name smartphone as a tool to find information and share other knowledge. Especially in a pandemic situation where smartphones become a primary need in life and work. Social media is a bridge for teachers and students and families to learn and communicate. This seems to be mutually understood by every member of the family. Even among participants, there were more than three social media. The pandemic situation is seen to affect the lifestyle and way of communication of family and community.

\section{Conclusion}

The study showed the significant findings of both independent variables studied in effecting family resilience. The findings found an origin side about the meaning of family resilience and its association with the polarization of work and social media in work and family life.

In addition, the study had methodological limitations because it focused on female subjects and did not include husbands and children as research subjects. Referring to the research and its limitations, future research is needed to detail the husband's work and income, household income, family monthly needs, the presence and function of a housekeeper, and social media communication patterns in the family.
In addition, building a sakinah family requires mutual respect from the couple related to work and personal boundaries. If needed, the pattern of setting working hours and family hours can be made or at least understand each other's treatment of their partners while working and at home. Included in this case is the agreement on the use of social media. The findings showed that the use of social media for personal use is a source of vulnerability in the family.

This reason of the family bound by the promise of the contract is read and accompanied by sighat taklik talaq. It means that the promise must be fulfilled and spoken and witnessed. The promise is witnessed and it means the bond is not something small but must be accounted for and maintained together in the pillar of zawaj. This pillar affirms that a household is not established alone, but together like nut and bolt that close each other. Understanding the role becomes important and done flexibly in teamwork and quality (Machrus, 2017), including the needs of the family. Having of housekeeper in the family becomes possible without reducing the role because the principle is only to be the role of housekeeper and is decided as deliberation. Islam teaches as an adaptive strategy in balancing the role and needs of the family. For governments and religious institutions, there is an attention to family and marriage development need to pay attention to the content of the role of husband and wife in marriage bond and how the use of technology is as part in strengthening marriage.

\section{References}

Al-Khasyt, M.U. (1999). Sulitnya Berumah Tangga; Upaya Mengatasinya menurut Qur'an Hadis dan Ilmu Pengetahuan. Jakarta: GIP.

As-Shawi, A.M. (2004). Hāsyiyyatus Shāwi ‘ alā Tafsirìl Jalālain, Beirut: Darul Fikr, juz I 
Agustina, M. W., \& Broto, G. W. (2019). Resiliensi Guru PAUD Honorer. Jurnal Happiness, 3(1).

Akbar, Z., \& Tahoma, O. (2018). Dukungan Sosial Dan Resiliensi Diri Pada Guru Sekolah Dasar. JPPP - Jurnal Penelitian Dan Pengukuran Psikologi, 7(1), 53-59. https://doi.org/10.21009/jppp.071.07

Basharpoor, S., \& Sheykholeslami, A. (2015). The relation of marital adjustment and family functions with quality of life in women. Europe's journal of psychology, 11(3), 432.

Bastaman, H. D. (2007). Logoterapi: Psikologi untuk Menemukan Makna Hidup dan Meraih Hidup Bermakna. Jakarta: Raja Grafindo Persada.

Clark, S. C. (2000). Work/family border theory: A new theory of work/family balance. Human relations, 53(6), 747770 .

Darmadi, H. (2015). Tugas, Peran, Kompetensi, dan Tanggung Jawab Menjadi Guru Profesional. Jurnal Edukasi, 13(2), 161-174.

Dumaris, S., \& Rahayu, A. (2019). Penerimaan diri dan resiliensi hubungannya dengan kebermaknaan hidup remaja yang tinggal di panti asuhan. Jurnal Sosial, 3(1), 7177.

Fergiliia, V., Kinanthi, M. roro, \& Brebahama, A. (2012). Resiliensi Keluarga Pada Keluarga Yang Memiliki Kedua Orangtua Bekerja. Schema Journal of Psychological Research, 104-115.

Fisher, G. G., Bulger, C. A., \& Smith, C. S. (2009). Beyond work and family: a measure of work/nonwork interference and enhancement. Journal of occupational health psychology, 14(4), 441.

Greenhaus, J. H., Collins, K. M., \& Shaw, J. D. (2003). The relation between workfamily balance and quality of life. Journal of vocational behavior, 63(3), 510-531.
Greenhaus, J. H., \& Powell, G. N. (2006). When work and family are allies: A theory of work-family enrichment. Academy of management review, 31(1), 72-92.

Grzywacz, J. G., \& Carlson, D. S. (2007). Conceptualizing work-family balance: Implications for practice and research. Advances in developing human resources, 9(4), 455-471.

Hakim, C. (2002). Lifestyle preferences as determinants of women's differentiated labor market careers. Work and occupations, 29(4), 428-459

Hawley, D. R., \& Dehaan, L. (1996). Toward a Definition of Family Resilience: Integrating Life-Span and Family Perspectives. Family Process, 35(3), 283-298. https://doi.org/10.1111/j.15455300.1996.00283.x

Jones, F., Burke, R. J., \& Westman, M. (Eds.). (2013). Work-life balance: A psychological perspective. Psychology Press.

Keene, J. R., \& Quadagno, J. (2004). Predictors of perceived work-family balance: Gender difference or gender similarity?. Sociological

Perspectives, 47(1), 1-23.

Knaub, P, K. (1986). Growing Up in A DualCareer Family: The Children's Perceptions. Family Relations, 35, 431437.

Kumar, A., \& Priyadarshini. (2018). Study to Measure the Impact of Media sosialUsage on Work-life Balance. Journal of IOP Conf. Series: Materials Science and Engineering, 390.

Mackay, R. (2003). Family Resilience and Good Child Outcomes: an Overview of the Research Literature. Social Policy Journal of New Zealand, 20.

Mahrus, A. (2017). Fondasi keluarga sakinah. Jakarta: Kementerian Agama RI

Marks, S. R., \& MacDermid, S. M. (1996). 
Multiple roles and the self: A theory of role balance. Journal of Marriage and the Family, 417-432.

Mawarpury, M., \& Mirza, M. (2017). Resiliensi Dalam Keluarga: Perspektif Psikologi. Psikoislamedia: Jurnal Psikologi, 2(1), 96. https://doi.org/10.22373/psikoislamedia. v2i1.1829

Nevid, J. ., Rathus, S. P., \& Greene, B. (2005). Psikologi Abnormal (5th ed.). Jakarta: Erlangga.

Patterson, J. . (2002). Integrating Family Resilience and Family Stress Theory. Journal of Marriage and Family, 64, 349-360.

Poegoeh, P. D., \& Hamidah. (2016). Peran Dukungan Sosial dan Regulasi Emosi terhadap Resiliensi Keluarga Penderita Skizofrenia. INSAN, 01(01), 138.

Redaksi. (2020). Pandemi Covid-19, Beban Tambah Berat Guru Harus Semangat. Retrieved from Rembangkab.go.id website:

https://rembangkab.go.id/berita/pandemi -covid-19-beban-tambah-berat-guruharus-semangat/

Reivich, K., \& Shatte, A. (2002). The Resilience Factor: 7 Essential Skill For Overcoming Life's In Obstacle. New York: Broadway Books.

Stafford, D., \& Griffis, H. (2008). A review of millennial generation characteristics and military workforce implications. Center for Naval Analysis, (May). Retrieved from http://citeseerx.ist.psu.edu/viewdoc/dow nload?doi=10.1.1.148.7496\&rep=rep1\&t ype $=$ pdf

U, S. M. (2015). Kedudukan Guru Sebagai Pendidik: Tugas dan Tanggung Jawab, Hak dan Kewajiban, dan Kompetensi Guru. Auladuna, 2 No.2, 221-232. https://doi.org/10.1016/S00029149(01)01484-9
Voydanoff, P. (2004). Implications of work and community demands and resources for work-to-family conflict and facilitation. Journal of Occupational Health Psychology, 9(4), 275.

Walsh, F. (1996). The Concept of Family Resilience: Crisis and Challenge. Family Process, 35(3), 261-281. https://doi.org/10.1111/j.15455300.1996.00261.x

Walsh, F. (2002). A family resilience framework: Innovative practice applications. Family Relations, 51(2), 130-137. https://doi.org/10.1111/j.17413729.2002.00130.x 